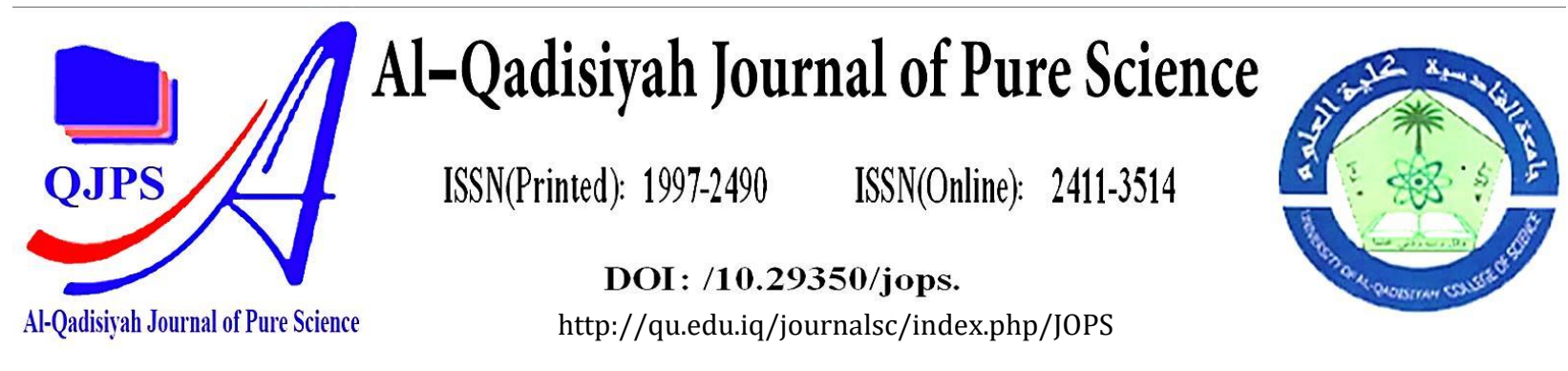

\title{
Effect of magnesium oxide nanoparticles on growth and biochemical content of blue-green alga Wollea salina
}

\begin{tabular}{|c|c|}
\hline Authors Names & ABSTRACT \\
\hline $\begin{array}{l}\text { b. Zahra K.M. Al-Khazali } \\
\text { Article History } \\
\text { Received on: } 25 / 6 / 2021 \\
\text { Revised on: } 11 / 7 / 2021 \\
\text { Accepted on: } 13 / 7 / 2021 \\
\text { Keywords: } \\
\text { Key words: magnesium } \\
\text { nanoparticles, wollea salina, } \\
\text { chlorophyll, proteins, } \\
\text { carbohydrates, lipids. } \\
\text { DOI: https://doi.org/10.29350/ } \\
\text { jops. 2021.26. 4.1396 }\end{array}$ & 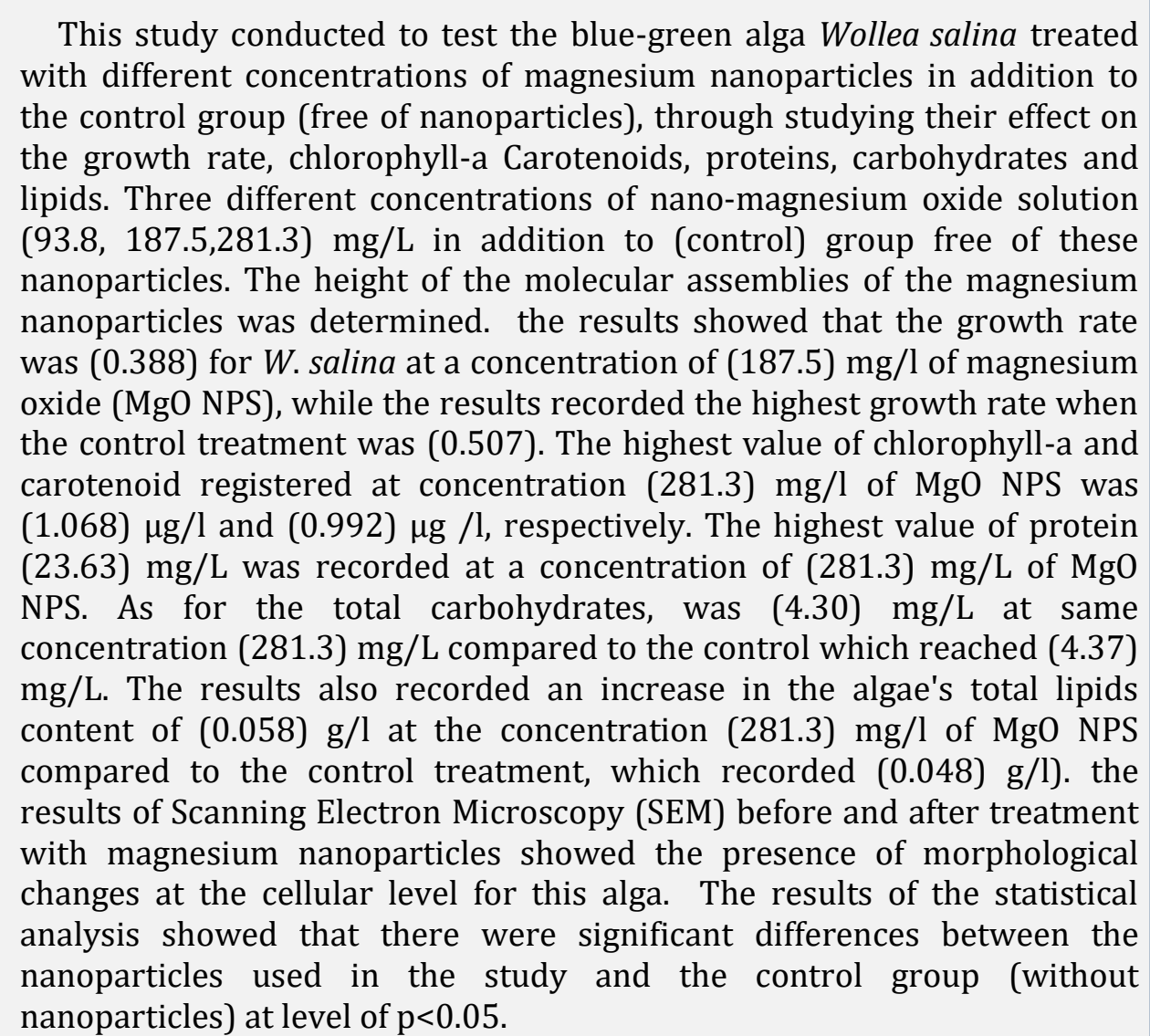 \\
\hline
\end{tabular}

a,b Biology Department, College of Education, University of Al-Qadisiyah, Iraq

${ }^{*}$ Corresponding Author: Haider A. Alghanmi, Biology Department, College of Education, University of Al-Qadisiyah, Iraq, email:

haider.alghanmi@qu.edu.iq, Mobile +96407831319132, ORCID: 0000-0002-6078-3145. 


\section{Introduction}

The nanoparticle technology is considered one of the latest scientific technologies, and it is a field of applied sciences that covers a wide range of topics, as it uses materials at the level of dimensions (1100) nanometers [15]. Due to their unique properties, nanoparticles are being used in biotechnology, Withe the development of biotechnologies, nanotechnology has been applied to some living organisms, including algae, and it was the focus of researchers' interest in terms of studying it and identifying the important characteristics in it and knowing its physiological characteristics and chemical content, because algae occupies a great importance in the aquatic environment, as it is the main product in the ecosystem [21]. It also represents the basic base of life in aquatic environments, being the direct and indirect food source for all living things, and thus constitutes the basic base of the food chain in these environments, algae is a great storehouse for many chemical compounds and an important source of many active substances and compounds, including proteins, carotenoids, lipidty acids and vitamins [14]. There are several factors that affect the distribution of algae and their abundance, including plant nutrients (Couple et al. 2012), as algae need a large number of nutrients that play an important role in their growth, and algal cells cannot dispense with these elements. Also, the change in the concentration of nutrients (increased or decrease) may cause a change in the composition of the algal community [28] Magnesium is an essential macronutrient and is a necessary activator of many enzymes such as Ribulose-1,5-bisphosphatecarboxylase/oxygenase and Phosphoenolpyruvate carboxylase (PEPC), both of which are essential enzymes in carbon fixation. Magnesium also plays an important role in the process of photosynthesis, because it forms the central atom in the chlorophyll molecule,It mediates the steric structure of the chlorophyll molecule, which is the basic compound for the photosynthesis process, which is the most important physiological process in plants and algae, according to which carbohydrates are formed. Therefore, low amounts of magnesium lead to a decrease in Photosynthesis and enzymatic activity [9]. Due to the vital importance of this element to algae, and for this reason on the one hand, and the fact that studies on the effect of nanoparticles on algae are few, and information on the effects of magnesium nanoparticles on algae is not available, so this study aimed to know the effect of different concentrations of magnesium nanoparticles on the growth and physiology of blue-green algae, Wollea salina by studying the effect of those minutes on growth rate, chlorophyll a-, carotenoids, proteins, carbohydrates and lipids.

\section{Materials and Methods}

\subsection{Algae isolation}

Samples of the blue-green alga Wollea salina were collected from Al-Hakim district in AlDiwaniyah city, southern Iraq, where they were isolated from the soil. They were purified and the effect of nanoparticles on the physiology of the algae under study was studied. The studied alga was isolated according to the agar dish planning method described by [25] using (BG-11) Medium and its components were shown by [20] which has been modified by [1]. To get a pure axenic culture from $W$. salina The Density Gradient Centrifugation method [29] was used. To ensure that the culture is free of bacteria and fungi, the final examination was carried out, which included culturing a sample of the algal culture on the solid Nutrient agar media for bacterial testing and incubated at $37{ }^{\circ} \mathrm{C}$ for 72 hours to ensure its purity and to reach the pure Axenic culture (Anderson, 2005). The isolates were grown with three replications for treatment and control under $25 \pm 2{ }^{\circ} \mathrm{C}$ and illumination intensity of 40 micromole/m2/sec. Light system 8:16 hours Lighting: Dark.

\subsection{Examination of algae using a compound light microscope:}

Examination of algae using a compound light microscope, the blue-green alga W. salina was diagnosed using taxonomic key [6].

2.3 Preparing the algae for examination by a scanning electron microscope (S.E.M.) 
For the purpose of imaging algae by scanning electron microscope (SEM) before and after treating them with magnesium nanoparticles, basic steps were followed in chemically treating algae, based on [8].

\subsection{Research experiments}

2.4.1 Characteristics of the nanocomposites used in the study:

Magnesium nanoparticles were purchased from the local market ready in the form of nanoscale magnesium oxide, which belongs to one of the approved Chinese companies, Nanjing High Technology Nano Material (HTNano), in a powder form, with a purity of $99 \%$, and a size (30-40) nanometers.

\subsection{Examination of nanocomposites using Atomic force microscopy (AFM)}

Magnesium nanoparticles were examined by atomic force microscopy (AFM) for the purpose of identifying and mapping surfaces with nanoscale dimensions.

\section{4 .3 preparation of nano-solutions}

Stock Solution for the studied nanocomposites (magnesium) was prepared from magnesium oxide nanocomposites (MgO NPs) for the purpose of using them in the preparation of the culture medium (BG-11) instead of the ordinary magnesium salts $\mathrm{MgSO} 4.7 \mathrm{H} 2 \mathrm{O}$. (37.52, 75, 112.52) $\mathrm{g}$ of nano-magnesium oxide were dissolved in a liter of deionized water, then the solutions were sterilized by autoclave and kept in the refrigerator at a temperature of $4^{\circ} \mathrm{C}$ until use and application. After the nanomaterial was suspended with distilled water, it was mixed using an ultrasonic homogenizer for a period of $15 \mathrm{~min}$. as these nano-solutions were mixed in order to prevent agglomeration of these materials [7].

\section{4 .4 Treatment of algae with the concentrations of the studied metal nanoparticles:}

Three different concentrations of magnesium nanocomposites $(93.8,187.5,281.3) \mathrm{mg} / \mathrm{L}$ were used for the purpose of growing the blue-green alga $W$. salina in the culture medium (BG-11) and comparing the effect with the control) free of nanocomposites). Readings daily to follow the growth curve, where the absorbance reading was taken and the chemical content of the algae was measured.

\section{4 .5 Experiment of growing the algae W. salina at nano concentrations and medium (BG-11):}

$10 \mathrm{ml}$ of $W$. salina was grown in four cultures, three of them contained different concentrations of nano magnesium solution $(93.8 \cdot, 187.5,281.3) \mathrm{mg} / \mathrm{L}$ where the first concentration represented less than the concentration in the culture media (BG-11) The second concentration is the same as the concentration originally found in the culture medium, while the third concentration is higher than the concentration found in the culture medium, As for the fourth farm, it was limited to the presence of only the development medium free of nanomaterials as a control parameter for the purpose of comparison.

2.4 .6 Measuring the growth rate of the algae used in the study:

The absorbance of all treatments was measured daily at a wavelength of $750 \mathrm{~nm}$ for the purpose of identifying the density of the algae. The growth rate $(\mu)$ and the doubling time $(\mathrm{G})$ were also estimated based on [19] according to the following equation:

$$
\mu=\ln (\mathrm{X} 1 / \mathrm{Xo}) / \mathrm{t}
$$

As for the doubling time $\mathrm{G}$, it was calculated from the following equation:

$$
\mathrm{G}=\ln 2 / \mu
$$


The method presented by [31] was adopted to measure the chlorophyll-a and carotenoid content of algae samples according to the following equations.

Chla $[\mu \mathrm{g} / \mathrm{L}]=12.9447(\mathrm{~A} 665-\mathrm{A} 720)$

Carotenoids $[\mu \mathrm{g} / \mathrm{L}]=[1,000(\mathrm{~A} 470-\mathrm{A} 720)-2.86(\mathrm{Chla}[\mu \mathrm{g} / \mathrm{ml}])] / 221$

\subsubsection{Protein content estimation:}

The protein content of the crude extract of algae was estimated by the Lowry method [13]. Which in estimating the amount of protein depends on the formation of a blue color when adding FolinCiocalteu formula and based on the curve of Bovine Serum Albumin (BSA) as a standard solution for the work of the standard curve for protein determination.

\subsubsection{Estimation of carbohydrate content:}

The total carbohydrate content of the same filtrate residue was estimated by the method of [5]. The optical density was measured using a spectrophotometer and using the standard curve for glucose, the total carbohydrate concentration was calculated. (Figure 2).

\subsubsection{Total lipid content}

The oil was extracted from the algal material according to the method of [3], and lipids were calculated as in the equation:

Total lipid $=($ weight of lipid in aliquot $\times$ volume of chloroform layer $) /($ volume of aliquot $)$

\section{Results and discussion}

3.1 Algal isolates used in the current study:

The blue-green algae W. salina was selected and classified according to microscopy after it was isolated, purified, and then grown on BG-11 culture medium (Figure 1).

\section{Empire: Prokaryota}

Kingdom: Eubacteria

Subkingdom: Negibacteria

Phylum: Cyanobacteria

Class: Cyanophyceae

Subclass: Nostocophycidae

Order: Nostocales

Family: Nostocaceae

Genus: Wollea

Species: salina 
Cells of Wollea salina were examined microscopically, this alga belongs to the phylum Cyanobacteria, the order Nostocales, and the Nostocaceae family, and the genus Wollea is one of five genera in this family [12]. Filamentous colonies and trichomes are parallel and dense surrounded by a transparent gelatinous sheath. The filament consists of a series of vegetative cells resembling a rosary. The cells are barrel-shaped to cylindrical in length (1.5-2) macrometer and width (1.6) macro meter, interspersed with larger and spherical cells are heterocysts that are oval the shape is barrel-shaped and slightly wider than the vegetative cells. The algal filament also contains the static cell Akinetes, which are cylindrical in the beginning and later turn into oval or oblong and are larger than the vegetative cells. Representing proliferative cells [11]. (Figure 1).

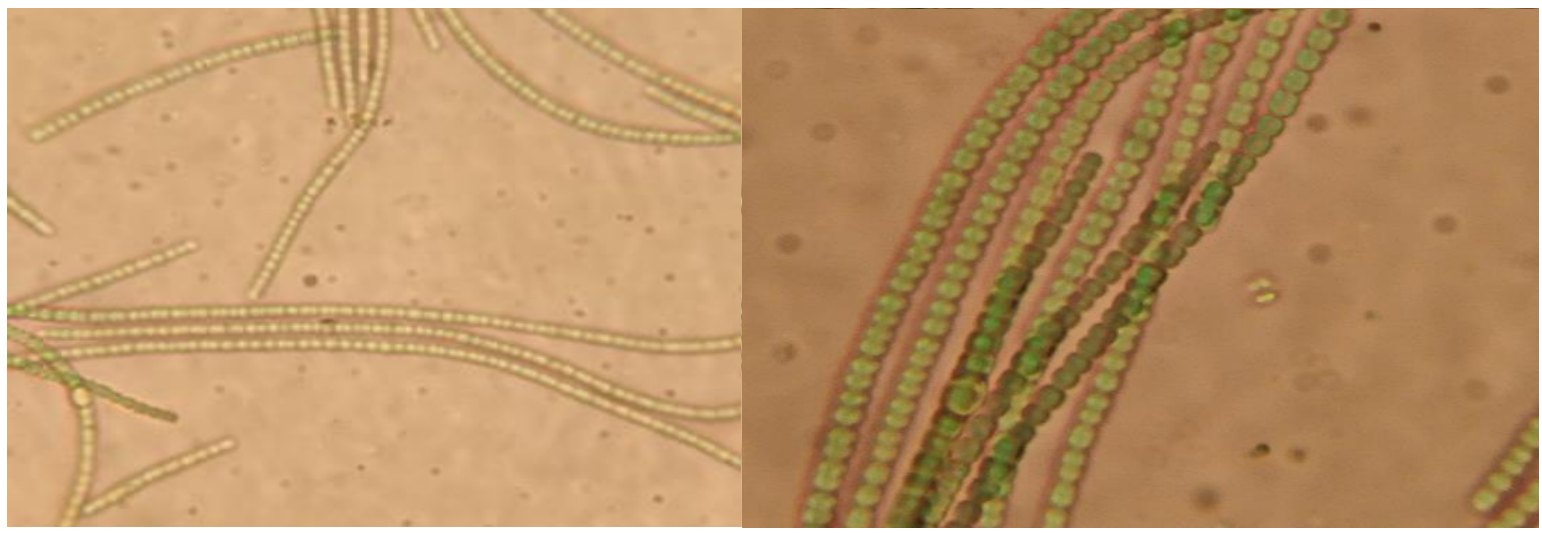

Fig. 1- W. salina under light microscope (40X).

\subsection{Examination of algae using a scanning electron microscope}

algae were photographed with a scanning electron microscope (SEM) before being treated with magnesium nanoparticles, and the imaging results showed the presence of some diagnostic characteristics of the algae under study, including phenotypic characteristics. It is transparent as it is interspersed with larger and spherical cells, which are heterocysts, which are oval to barrel-shaped and slightly wider than the vegetative cells. (Figure 2).
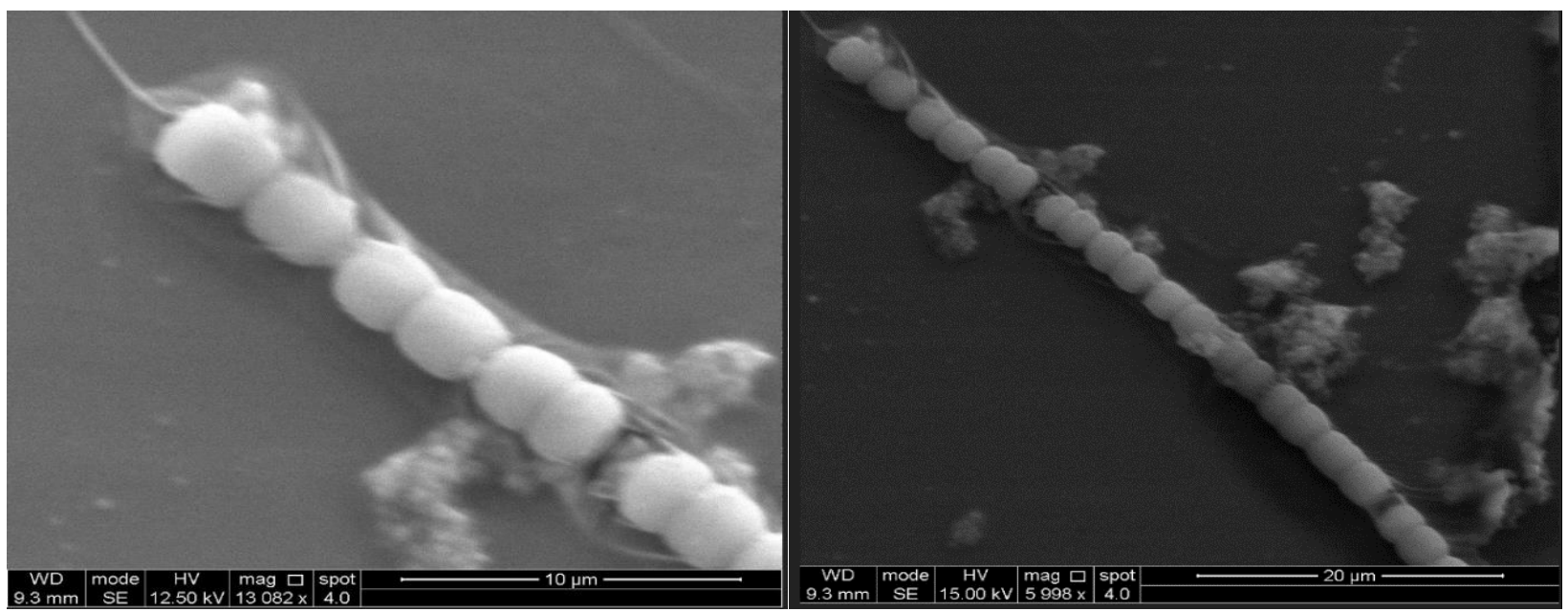

15.00 KV magnification power and $9.3 \mathrm{~mm}$ precision $12.50 \mathrm{KV}$ magnification power and $9.3 \mathrm{~mm}$ precision.

Fig. 2- W. salina by scanning electron microscopy (SEM) before treatment with nanoparticles. 


\subsection{Examination of nanocomposites using atomic force microscopy (AFM).}

Two- and three-dimensional diagrams of the surface topography of nanomaterials (magnesium oxide) at the atomic level were drawn by Atomic force microscopy (AFM), and the type and location of each atom were determined on the three-dimensional diagram of the topography of the surface of the material at the atomic level. As the outer surface of the copper nanoparticles under study was studied, and (Figure 3 -A) shows a two-dimensional image of magnesium nanoparticles showing molecular assemblies with semi-spherical shapes, and (Figure 3- B) shows a three-dimensional image of a section of the surface of magnesium nanoparticles, in which the height of the molecular assemblies is observed At $466 \mathrm{~nm}$, it turns out that the average particle sizes were about $35 \mathrm{~nm}$.

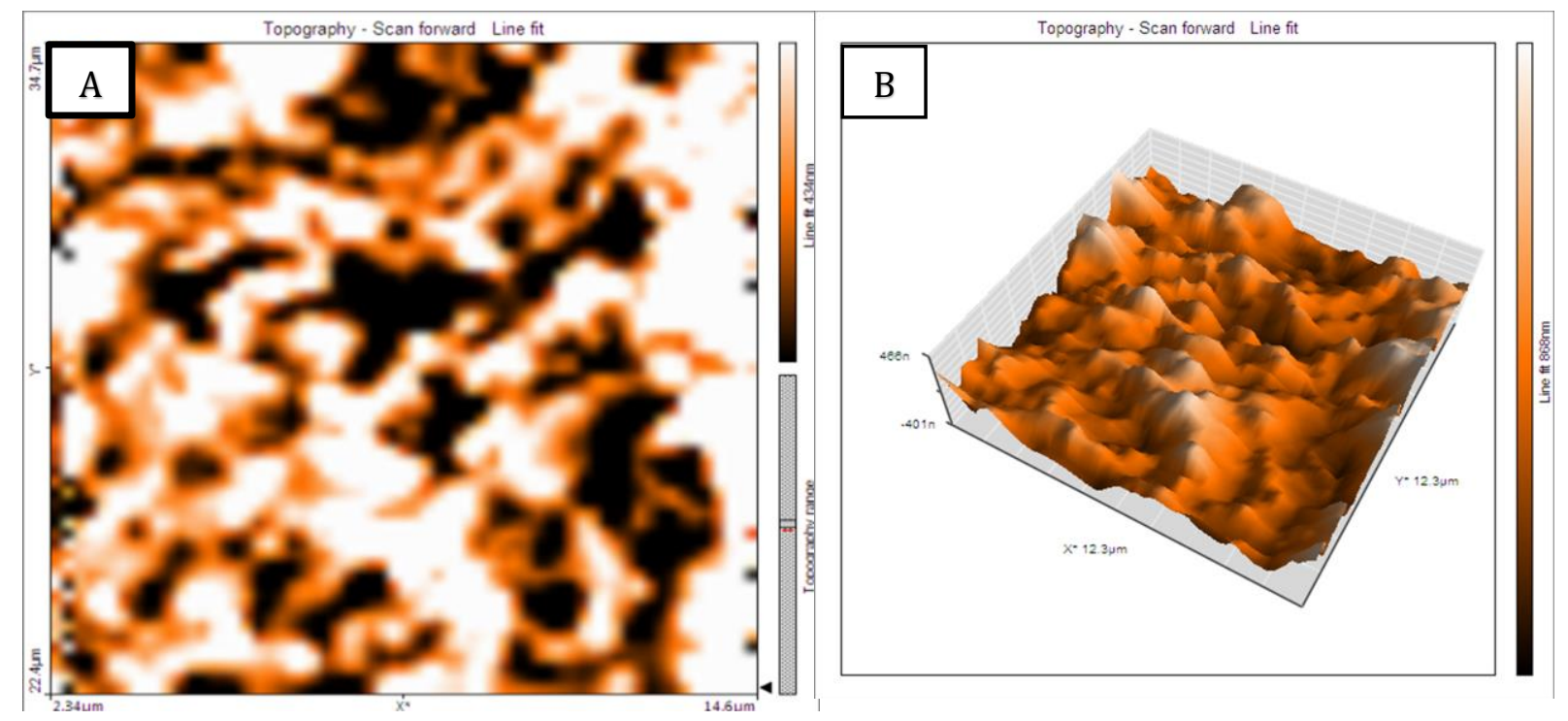

Fig. 3- magnesium oxide nanoparticles used in the study under an atomic force microscopy (AFM).

\subsection{Effect of different concentrations of magnesium nanoparticles on the growth and cellular components of $W$. salina:}

Imaging results by scanning electron microscopy (SEM) after treating the algae with magnesium nanoparticles showed that these particles affected the morphological characteristics of the blue-green algae W. salina when the concentration was increased, which led to a change in the shape of the cells through a contraction in the size of the cytoplasm and thus distorting the cells Algae (Figure 4). 


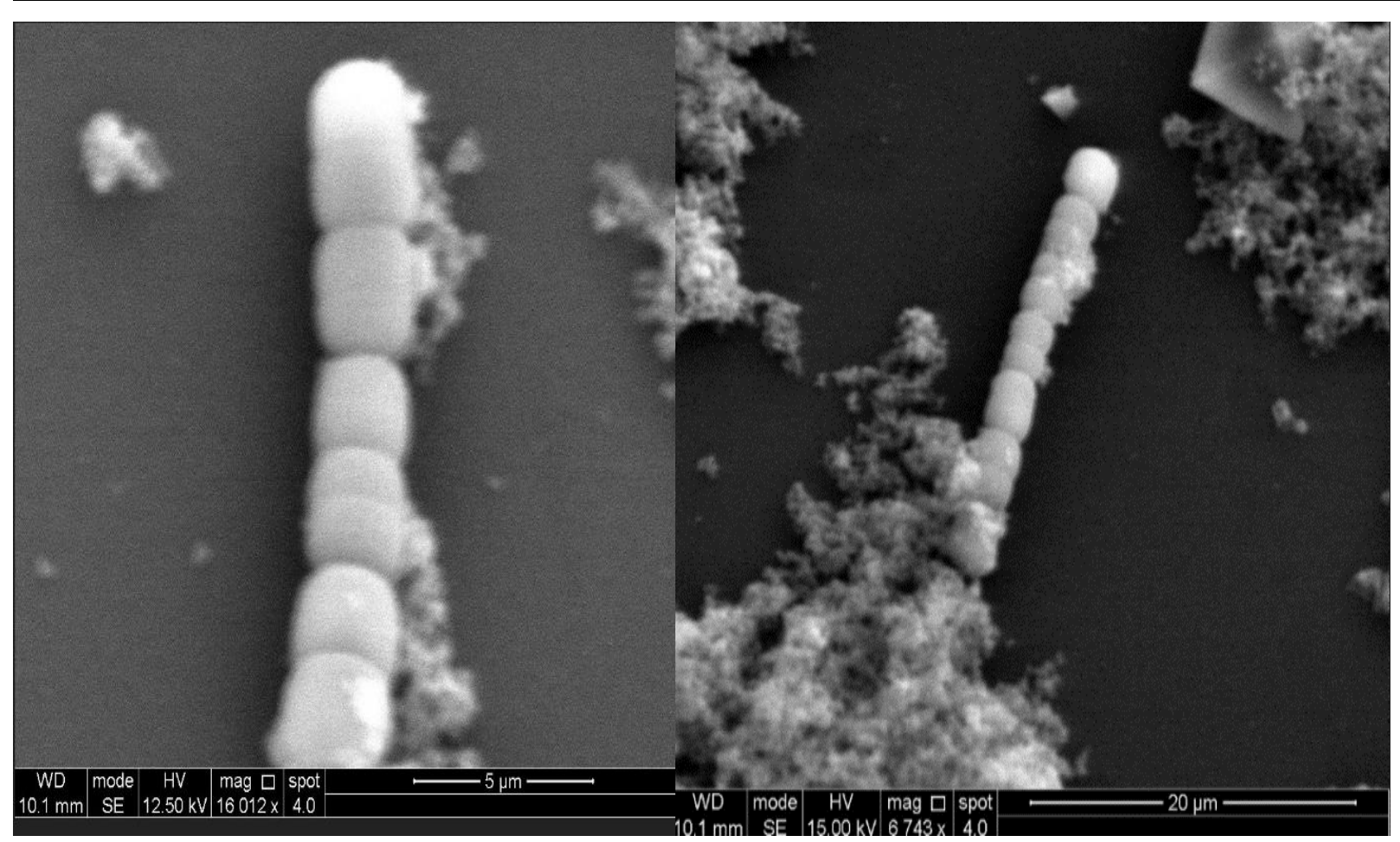

\section{Fig. 4- W. salina by scanning electron microscopy (SEM) after treatment with magnesium oxide nanoparticles.}

The results of the study, when exposing the blue-green alga $W$. salina to magnesium nanoparticles, showed that the optical density values at the concentration (187.5) $\mathrm{mg} / \mathrm{L}$ of nano-magnesium originally present in the culture media reached 0.095, while it increased at the highest concentration (281.3) $\mathrm{mg} / \mathrm{L}$ with its highest rate $(0.114)$, but it did not reach the limit recorded in the control (0.139), while it decreased in the lowest concentration (93.8) $\mathrm{mg} / \mathrm{L}$ to reach (0.059) (Figure 5).

It is noted from the results that the growth of $W$. salina algae, which was estimated in terms of optical density when growing in nano-magnesium concentrations, reached the highest growth rate $(\mu=880.3)$ when the alga was treated with nano-magnesium oxide concentration $(281.3) \mathrm{mg} / \mathrm{l}$, and the growth rate was $\mu=(0.323)$ when the algae was treated with nano-magnesium concentration $(187.5) \mathrm{mg} / \mathrm{l}$, while the lowest growth rate was $\mu=(0.268)$ when the algae was treated with nano-magnesium concentration $(93.8) \mathrm{mg} / \mathrm{l}$ in comparison with the control where the growth rate was $(\mu=0.455))$ As for the average doubling time, it was (4.723, 3.560 and 3.923 ) days in concentrations (93.8, 187.5, 281.3), respectively, compared with the control 3.375. days (Table 1). The results of the statistical analysis showed that there were significant differences between the growth values per day and between the concentrations at $\mathrm{P} \leq 0.05$ ).

The occurrence of growth due to the use of the above concentration of magnesium nanoparticles, which is higher than the concentration originally found in the culture media, is due to the role of these particles in increasing the area of reactions and enzymatic activities and their rates, which leads to the production of sufficient raw materials for the continuation of cell division [16], Nanoparticles also stimulate photosynthesis enzymes [24] and thus affect photosynthesis reactions and chlorophyll formation, and then influence growth [17]. Thus, the effect of nanoparticles on algae may be beneficial for their growth, depending on the type, concentration and size of nanoparticles [2]. In addition, 
magnesium is an important element as it plays a key role in the formation of the chlorophyll molecule and the photosynthesis process of plants and algae [22].

As for the value of chlorophyll-a dye in $W$. salina when grown with nano-magnesium concentrations, it reached the highest value (1.068) $\mu \mathrm{g} / \mathrm{l}$ when the alga was treated with nanomagnesium concentration $(281.3) \mathrm{mg} / \mathrm{l}(0.87) \mu \mathrm{g} / \mathrm{l}$ when treated with nano-magnesium concentration. (187.5) $\mathrm{mg} / \mathrm{l}$, while the lowest value of chlorophyll-a pigment was $(0.675) \mu \mathrm{g} / \mathrm{l}$ when the algae was treated with a concentration of nano-magnesium (93.8) $\mathrm{mg} / \mathrm{l}$ compared to the control, which amounted to $(1.11) \mu \mathrm{g} / \mathrm{l}$ as shown in the figure (6). The results of the statistical analysis showed that there were significant differences between the values of chlorophyll-a dye per day in the different concentrations of nano-copper at the level of 0.05 , meaning that $(\mathrm{P} \leq 0.05)$. Thus, the high values of chlorophyll-a when using magnesium nanoparticles at high concentrations may be attributed to the role of nanoparticles in improving biological activities [21] and increasing enzymatic activities leading to stimulating chlorophyll divisions as well as stimulating photosynthesis enzymes, It also works to increase the activity of enzymes catalyzing to stop the production of ethylene and inhibit its work, which has a role in the activity of the enzyme chlorophyll oxidation, chlorophyllase, which destroys chloroplasts, and thus, nanoparticles work to keep the plastids alive for a longer period [24] this leads to an increase in the efficiency of photosynthesis (Lipidoba and Udoh, 2008). The results of the current study agreed with the study of (Sarma et al.2014) on the alga Chlorella vulgaris when treated with magnesium nanoparticles, as it was shown that magnesium is an essential element in the chlorophyll molecule, and there was an increase in the chlorophyll-a content of the green alga Chlorella vulgaris when treated with magnesium nanoparticles However, it remained uncontrollable.

The value of the carotenoid pigment in W. salina, when grown with nano-magnesium concentrations, reached the highest value $(0.992) \mu \mathrm{g} / \mathrm{L}$ when the alga was treated with nano-magnesium concentration (281.3) $\mathrm{mg} / \mathrm{L}(0.901) \mu \mathrm{g} / \mathrm{L}$ when treated with nano-magnesium (187.5) $\mathrm{mg}$. While the lowest value of carotenoids dye was (0.64) $\mu \mathrm{g} /$ liter when the algae was treated with a concentration of nanomagnesium (93.8) $\mathrm{mg} /$ liter compared to the control, which amounted to (1.316) $\mu \mathrm{g} / \mathrm{liter}$ as shown in the figure (7) The results of the statistical analysis showed that there were significant differences between the values of carotenoid dye per day in the different concentrations of nano-copper at the level of 0.05 , meaning that $(\mathrm{P} \leq 0.05)$. Algae are sources of natural pigments [14]. The reason for the algae's high content of carotenoids as a result of treatment with magnesium nanoparticles may be due to the positive effect of magnesium oxide nanoparticles in the production of growth materials. [10] confirmed that nanoparticles are biologically active as a result of the enormous surface area per unit volume compared to large bodies of the same chemical composition., as demonstrated by a 2017 study [23] on the green alga Chlorella vulgaris, the use of magnesium nanoparticles at a concentration of 200 $\mathrm{mg} / \mathrm{L}$ produced the highest content of carotenoids $0.69 \mu \mathrm{g} / \mathrm{L}$, but it was lower than the values recorded in the control $1.79 \mu \mathrm{g} / \mathrm{L}$. These results are consistent with the findings of the current study.

As for the protein value of $W$. salina alga when grown with nano-magnesium concentrations, it reached the highest value 023.63$) \mathrm{mg} / \mathrm{l}$ when the alga was treated with nano-magnesium concentration (281.3) $\mathrm{mg} / \mathrm{l},(22.68) \mathrm{mg} / \mathrm{l}$ when treated with nano-magnesium (187.5) $\mathrm{mg} / \mathrm{l}$, concentration. while the lowest value of protein was $(21.47) \mathrm{mg} / \mathrm{l}$ when the algae was treated with a concentration of nanomagnesium (93.8) $\mathrm{mg} / \mathrm{l}$ compared to the control, which amounted to (24.93) $\mathrm{mg} / \mathrm{l}$ as shown in Figure (8). The results of the statistical analysis showed that there were significant differences between the values of protein for one day at the level of 0.05 , meaning that $(\mathrm{P} \leq 0.05)$. The magnesium element affects the building of protein in cells by binding the ribosomes responsible for building the protein, in 
addition to the fact that magnesium is included in the composition of the cell wall. The protein formed the largest part or proportion of the chemical content of the studied algae compared to the rest of the contents represented by carbohydrates and lipids, and this was recorded with the current study. This is consistent with what was observed by other researchers, including [23] who noticed that the chemical analysis of $C$. vulgaris after treating it with different concentrations of nanoparticles showed that its protein content was higher than that of carbohydrates and lipids. Magnesium nanoparticles had stimulating effects, especially in high concentrations, because magnesium is one of the main elements and needed by algae in relatively large quantities. Therefore, it is one of the major elements, as it increases the activity of enzymes necessary in building proteins, The active role of magnesium in the course of physiological processes and chemical reactions comes from Being the center of the chlorophyll molecule, in addition to activating a number of enzymes that control the synthesis of proteins and the formation of chromosomes [22], And the positive approach of metallic nanoparticles to improve protein production in algae with a high concentration of magnesium nanoparticles is due to the role of nanoparticles in promoting growth represented by increasing chlorophyll, helped by the presence of nutrients, as the absorption of additional quantities of nutrients stimulates the manufacture of proteins.

The results of the current study showed that the carbohydrate content of $W$. salina when grown with nano-magnesium concentrations reached its highest value (4.30) $\mathrm{mg} / \mathrm{L}$ when treated with (281.3) $\mathrm{mg} / \mathrm{L}$ of nano-magnesium and(4.29) $\mathrm{mg} / \mathrm{L}$ when treated with concentration( 187.5$) \mathrm{mg} / \mathrm{L}$ of nanomagnesium, while it was less than carbohydrates (4.12) $\mathrm{mg} / \mathrm{L}$ when the algae was treated with a concentration of nano-magnesium (93.8) $\mathrm{mg} / \mathrm{L}$ compared to the control, which amounted to (4.37) $\mathrm{mg} / \mathrm{L}$

as shown in the figure (9), The results of the statistical analysis showed that there were significant differences between the values of protein for one day at the level of 0.05 , meaning that $(\mathrm{P} \leq 0.05)$. The increase in the proportion of carbohydrates at the highest concentration of nano-magnesium is due to the continuity of vital activities leading to its formation due to the activity caused by nanoparticles in increasing the area of biochemical reactions, as the role of nanoparticles is manifested in encouraging and improving the growth of algae [26], The results of the current study are in agreement with the study of [23] when studying the green alga Chlorella vulgaris, which indicated an increase in the carbohydrate content of the algae with an increase in the concentration of magnesium oxide nanoparticles, where carbohydrates were recorded at $28 \mathrm{mg} / \mathrm{L}$ at a concentration of $150 \mathrm{mg} / \mathrm{L}$ of nano-magnesium.

The current study also showed that carbohydrates formed the second place in the chemical content of the studied algae after proteins. With this result, the current study agreed with the study [23] when studying the algae Chlorella vulgaris, which indicated that carbohydrates came in second place after proteins when they studied the content The chemical alga $C$. vulgaris, but they did not agree with [27] which indicated that carbohydrates came first, then proteins came after them when they studied Chlorella, which contained (33.6\%) carbohydrates while it contained (25.4\%) of proteins.

The results of the statistical analysis showed that there were significant differences between the values of lipids at different concentrations of nano-magnesium oxide at the level of 0.05 , meaning that $(\mathrm{P} \leq$ 0.05). The lipid value of $W$. salina alga reached the highest value $(0.066) \mathrm{g} /$ liter at It was treated with a concentration of nano magnesium $(281.3) \mathrm{mg} / \mathrm{L}(0.057) \mathrm{g} / \mathrm{L}$ when treated with a concentration of nano magnesium (93.8) $\mathrm{mg} / \mathrm{L}$, while it was less than lipid (0.056) $\mathrm{g} / \mathrm{L}$ when the algae treated with a concentration of nano magnesium (187.5) $\mathrm{mg} / \mathrm{L}$ in comparison. With the control, which amounted to 
(0.058) g / liter, as shown in Figure (10). The algae in the current study generally contained less lipid than proteins and carbohydrates, and the results of the study recorded a clear increase in lipid values when treated with nano-magnesium at a concentration of $(281.3) \mathrm{mg} / \mathrm{L} \mathrm{mg} / \mathrm{L}$, which amounted to $(0.066) \mathrm{g} / \mathrm{L}$, which is a higher value than the control treatment $(0.058) \mathrm{g} / \mathrm{L}$ This may be due to the role of these particles in increasing the area of chemical reactions and enzymatic activities and their rates, which leads to the production of sufficient raw materials for cell division [18]. This is reflected in all vital components, including lipids, as the small size of the nano-nutrient compositions, which is in the range (1-100) nanometers, which are characterized by a high surface area and have abnormal characteristics, can result from a different behavior and lipids of nutrients within this structure compared to their larger similarities. [4], The reason for the high lipid may be because many strains of algae are able to produce more than $50 \%$ of their mass from lipids, and sometimes up to $80 \%$ because their photosynthesis mechanisms are similar to those of higher plants, and are often more efficient In converting solar energy into useful biochemical products such as oils, it grows in different aqueous solutions because of its simple cellular structure and its high efficiency in accessing water, carbon dioxide and other nutrients [30].

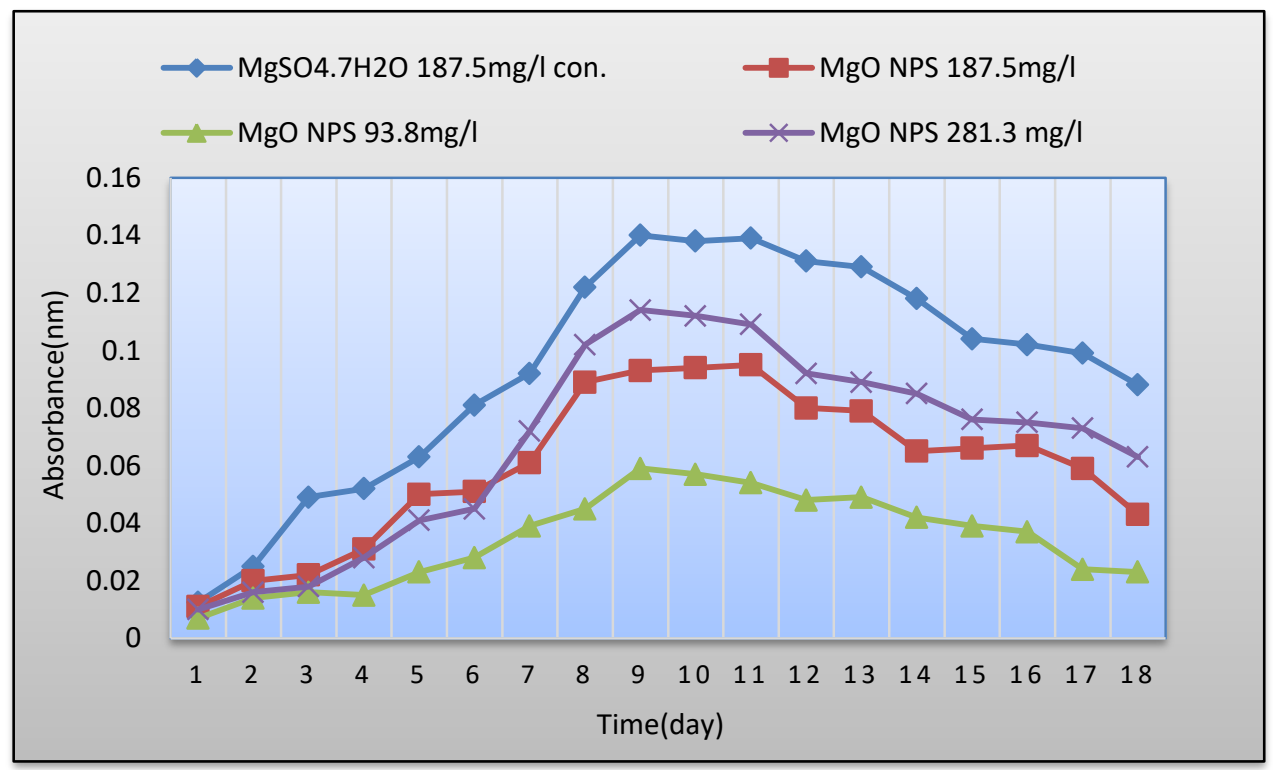

Fig. 5- The absorbance values of $W$. salina under three different concentrations of nanomagnesium oxide. 
Table (1): Growth rate and doubling time based on the absorbance values of $W$. salina when exposed to different concentrations of nano magnesium.

\begin{tabular}{|c|c|c|c|c|c|c|c|c|}
\hline \multirow[b]{2}{*}{$\begin{array}{l}\text { Tim } \\
\text { e } \\
\text { (day } \\
\text { ) }\end{array}$} & \multicolumn{4}{|c|}{ doubling time $\mathrm{G}$ (day) } & \multicolumn{4}{|c|}{ growth rate $\mu$} \\
\hline & $\begin{array}{c}\mathrm{MgSO} \\
4.7 \mathrm{H} 2 \\
\mathrm{O} \\
187.5 \\
\mathrm{mg} / \mathrm{l} \\
\text { control } \\
\end{array}$ & $\begin{array}{c}\mathrm{MgO} \\
\mathrm{NPS} \\
187.5 \mathrm{mg} \\
/ 1\end{array}$ & $\begin{array}{c}\mathrm{MgO} \\
\mathrm{NPS} \\
93.8 \mathrm{mg} / 1\end{array}$ & $\begin{array}{c}\mathrm{MgO} \\
\mathrm{NPS} \\
281.3 \\
\mathrm{mg} / \mathrm{l}\end{array}$ & $\begin{array}{c}\mathrm{MgSO} 4 . \\
7 \mathrm{H} 2 \mathrm{O} \\
187.5 \mathrm{mg} \\
/ 1 \\
\text { control }\end{array}$ & $\begin{array}{l}\mathrm{NPS} \mathrm{MgO} \\
187.5 \mathrm{mg} / \mathrm{l}\end{array}$ & $\begin{array}{c}\mathrm{MgONPS} \\
93.8 \mathrm{mg} / 1\end{array}$ & $\begin{array}{l}\mathrm{MgO} \text { NPS } \\
281.3 \mathrm{mg} / 1\end{array}$ \\
\hline 1 & 0 & 0 & 0 & 0 & 0 & 0 & 0 & 0 \\
\hline 2 & 1.998 & 2.539 & 3.415 & 2.159 & 0.347 & 0.273 & 0.203 & 0.321 \\
\hline 3 & 1.523 & 2.146 & 2.806 & 1.786 & 0.455 & 0.323 & 0.247 & 0.388 \\
\hline 4 & 1.947 & 2.521 & 3.165 & 2.075 & 0.356 & 0.275 & 0.219 & 0.334 \\
\hline 5 & 2.146 & 2.586 & 3.365 & 2.126 & 0.323 & 0.268 & 0.206 & 0.326 \\
\hline 6 & 2.229 & 2.432 & 3.667 & 2.280 & 0.311 & 0.285 & 0.189 & 0.304 \\
\hline 7 & 2.432 & 2.295 & 2.912 & 2.200 & 0.285 & 0.302 & 0.238 & 0.315 \\
\hline 8 & 2.432 & 2.295 & 2.586 & 2.358 & 0.285 & 0.302 & 0.268 & 0.294 \\
\hline 9 & 2.586 & 2.596 & 2.888 & 2.636 & 0.268 & 0.267 & 0.24 & 0.263 \\
\hline 10 & 2.888 & 2.876 & 3.398 & 3.081 & 0.24 & 0.241 & 0.204 & 0.225 \\
\hline 11 & 3.165 & 3.027 & 3.767 & 3.415 & 0.219 & 0.229 & 0.184 & 0.203 \\
\hline 12 & 3.536 & 3.648 & 4.530 & 4.279 & 0.196 & 0.19 & 0.153 & 0.162 \\
\hline 13 & 3.851 & 4.007 & 5.545 & 4.748 & 0.18 & 0.173 & 0.125 & 0.146 \\
\hline 14 & 4.332 & 4.530 & 5.874 & 5.291 & 0.16 & 0.153 & 0.118 & 0.131 \\
\hline 15 & 4.916 & 4.881 & 6.601 & 5.924 & 0.141 & 0.142 & 0.105 & 0.117 \\
\hline 16 & 5.291 & 5.501 & 7.001 & 6.730 & 0.131 & 0.126 & 0.099 & 0.103 \\
\hline 17 & 5.682 & 5.975 & 9.002 & 7.453 & 0.122 & 0.116 & 0.077 & 0.093 \\
\hline 18 & 6.418 & 6.665 & 9.763 & 8.155 & 0.108 & 0.104 & 0.071 & 0.085 \\
\hline $\begin{array}{c}\text { Avera } \\
\text { ge }\end{array}$ & 3.375 & 3.560 & 4.723 & 3.923 & 0.243 & 0.222 & 0.173 & 0.224 \\
\hline
\end{tabular}




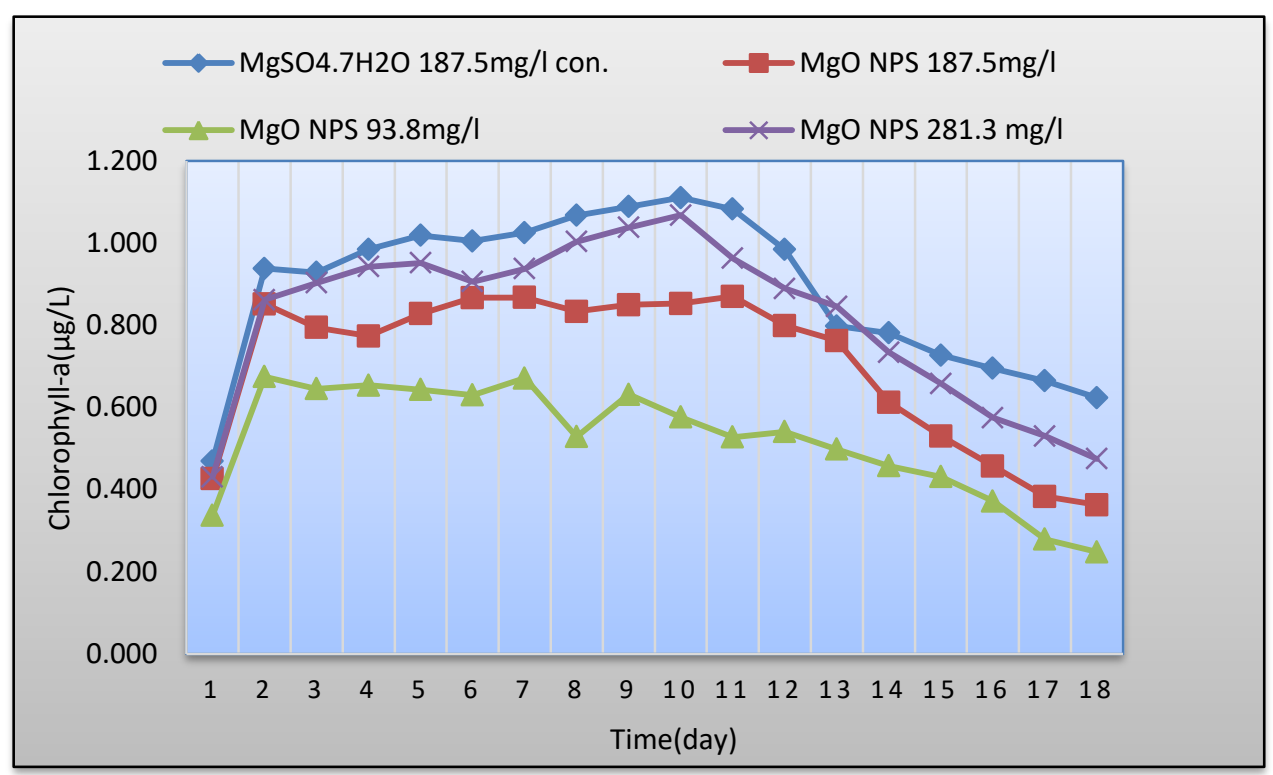

Fig. 6- Chlorophyll-a ( $\mu \mathrm{g} / \mathrm{L})$ of $W$. salina under three different concentrations of nano magnesium oxide

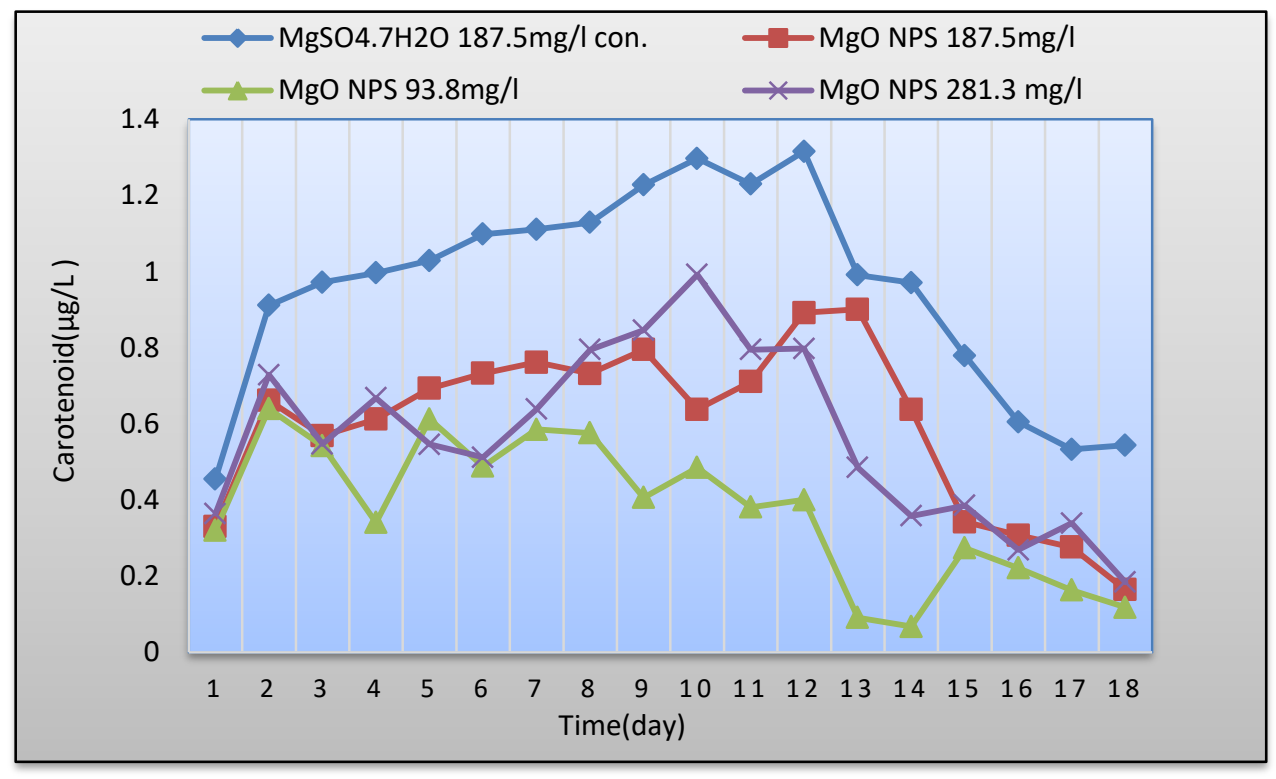

Fig. 7- The of carotenoids $\mu \mathrm{g} / \mathrm{L}$ of $W$. salina under three different concentrations of nanomagnesium oxide. 


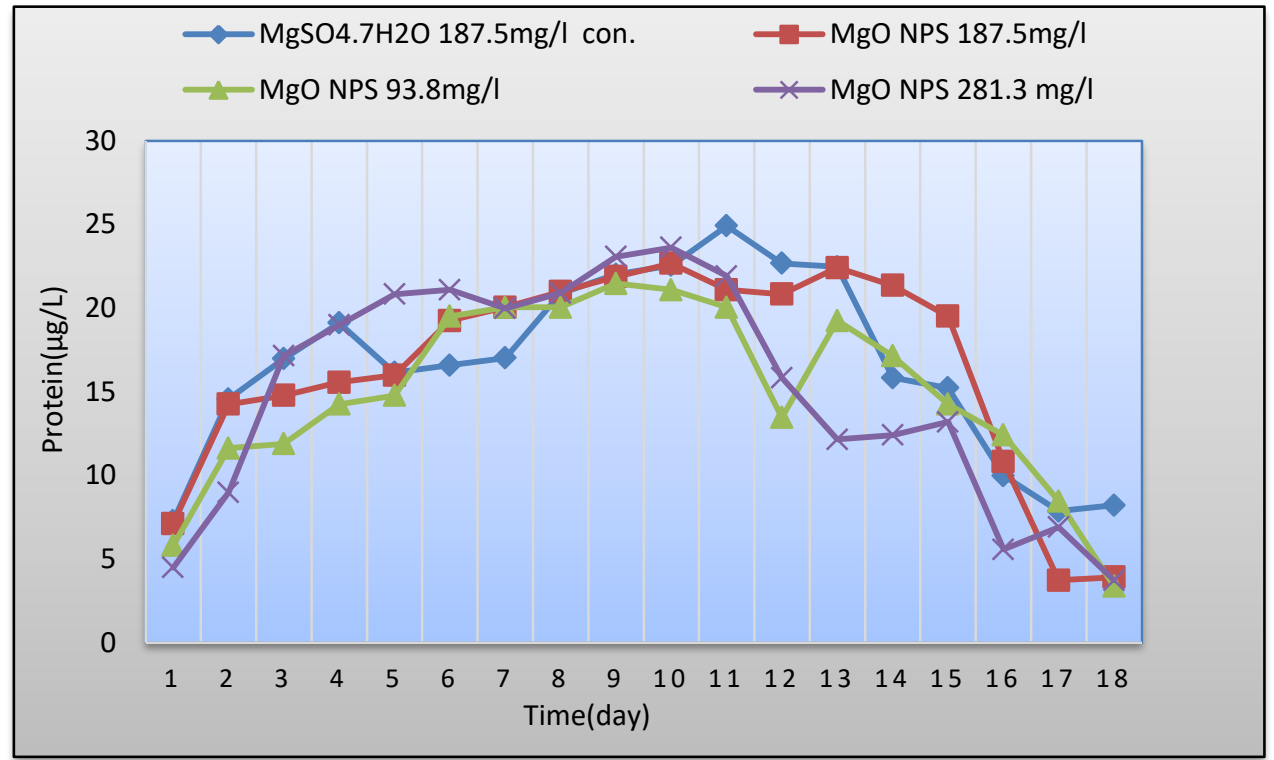

Fig. 8- The of Protein ( $\mu \mathrm{g} / \mathrm{L})$ of $W$. salina under three different concentrations of nanomagnesium oxide.

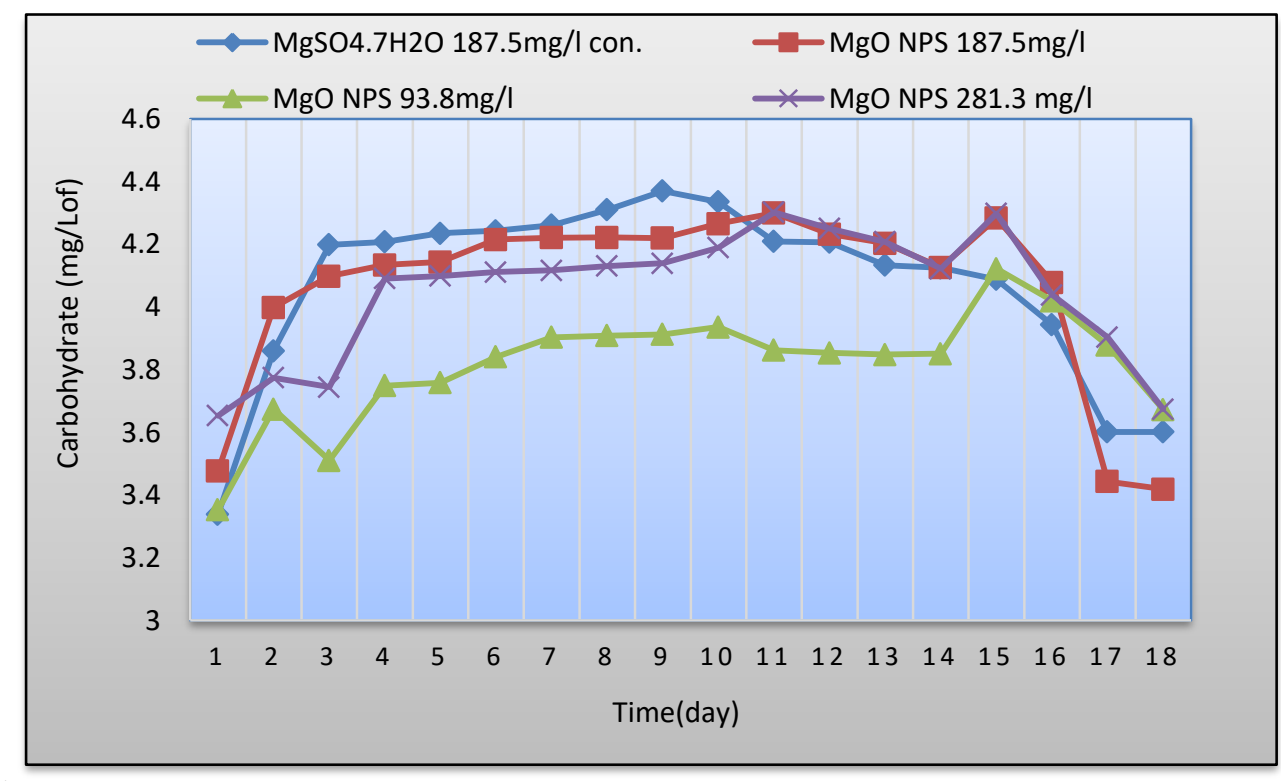

Fig. 9- Carbohydrate mg/Lof $W$. salina under three different concentrations of nano-magnesium oxide. 


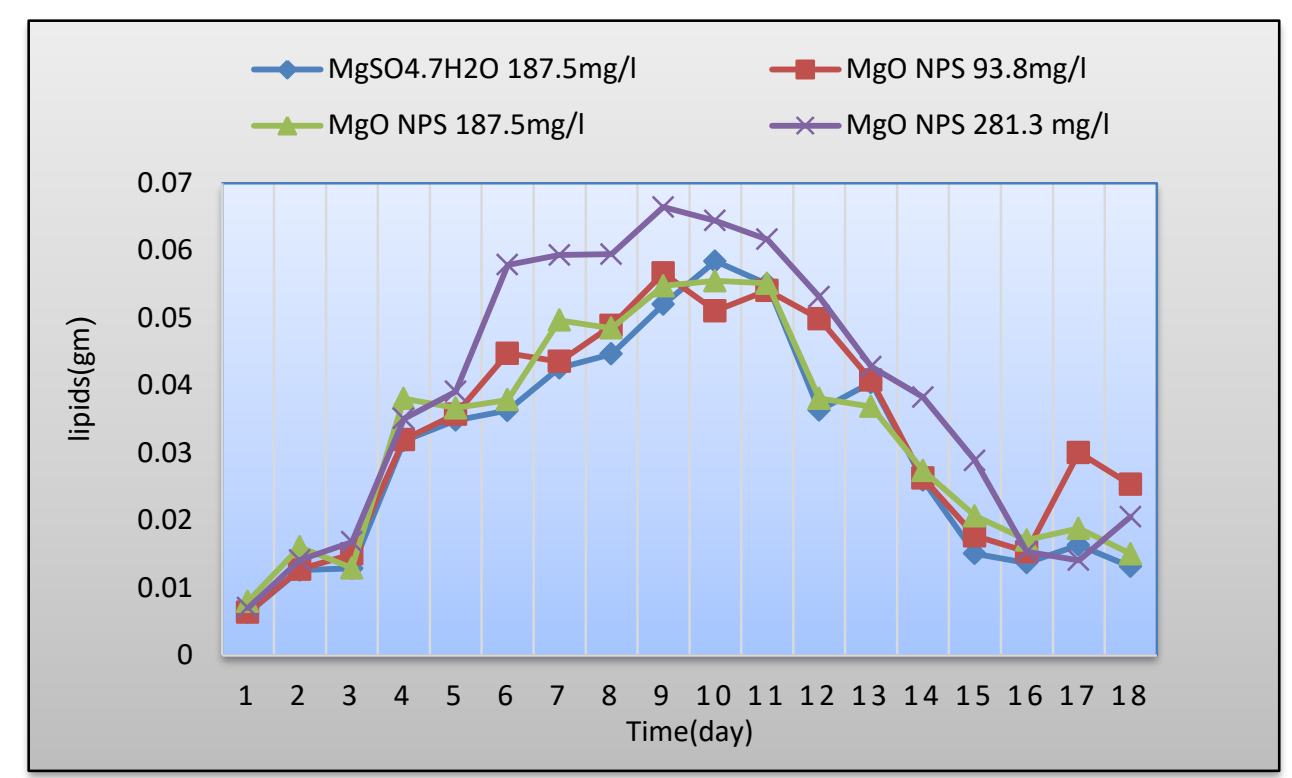

Fig. 10- The lipids g/L of $W$. salina under three different concentrations of nano-magnesium oxide.

\section{Conclusions:}

From the results obtained from the current study, the following conclusions can be drawn:

1-The high concentrations (281.3) $\mathrm{mg} / \mathrm{L}$ of MgO NPS nanoparticles under study had positive effects on the lipid content of the blue-green alga W. salina. Thus, the application of $\mathrm{MgO}$ nanoparticles could be a potential strategy to increase the lipid yield of the algae, making it a material a valuable raw material for biofuels.

2- The ability of the blue-green alga $W$. salina to withstand relatively high concentrations of MgO NPS nanoparticles used in the current study, which could be a catalyst for the accumulation of algal biomass.

3- The nanoparticles MgO NPS leading to inhibition the growth rate and chlorophyll a and carotenoid in comparative to the control group without MgO NPS.

\section{Reference:}

[1]- Andersen R.A.( 2005). Algal Culturing Techniques. Elsevier Academic Press; San Diego, CA, USA.

[2]- Aruoja,V; Pokhrel,S.; Sihtmäe,M.; Mortimer,M.; Mädler,Land Kahrua,A. (2012). Toxicity of 12 metal-based nanoparticles to algae, bacteria andprotozoa. Journal Name., 2013, 00: 1-3.

[3]- Bligh, EG. and Dyer, WJ. (1959). A rapid method of total lipid extraction and purification. Can J Biochem Physiol. 37:911-917. 
[4]- Brunner, T.J., P;Wick, P. ;Manser, P.;Spohn, R.N. ;Grass, L.K.; Limbach,A. and Stark,W.J.( 2006). In vitro cytotoxicity of oxide nano-particles: Comparison to asbestos, silica, and effects of particle solubility. Environ. Sci.Technol. 40:4374-4381.

[5]- Dubois, M.; Gilles, K.A.; Hamilton, J.K.; Repers, P.A. and Smith, F. (1956). Colorimetric method for determination of sugars and related substances. Anal Chem ,28(3): 350-356.

[6]- Guiry, M.D. and Guiry, G.M. (2019). Algae Base. World-wide electronic publication, National University of Ireland, Galway. http://www.algaebase.org; searched on 26 March 2019.

[7]- Haghi ,M. ; Hekmatafshar M. ; Janipour, M.B. ; Gholizadeh,S.S. ;Faraz,K.M. ; Farzad, S.; and Ghaedi,M. (2012). Antibbacterial effect of TiO2 Nanoparticales on pathogenic strain of $E$. coli. International Journal of Advanced Biotechnology and Research, 3 (3):621-624.

[8]- Hasle, G. R. and Syversten, E. E.(1997). Marine Diatoms. In: Tomas C.R. (ed.), Identifying Marine Diatoms and Dinoflagellates, Academic Press, San Diego: 5-385.

[9]- Hermans, C.; Vuylsteke, M.;Coppens, F.; Cristescu, S.M.; Harren F.J.M.; Inze, D. and Verbruggen, N.(2010). Systems analysis of the responses to long-term magnesium deficiency and restoration in Arabidopsis thaliana, The New Phytologist, 187( 1) : 132-144.

[10]- Hext, P.M.; Tomenson, J.A., and Thompson, P. (2005.)Titanium dioxide: inhalation toxicology and epidemiology, Ann. Occ. Hyg. 49 (6): 461-472.

[11]- Johansen, J.R. (2014). Taxonomic classification of cyanoprokaryotes (cyanobacterial genera), using a polyphasic approach. Preslia 86: 295-335.

[12]- Kozhevnikov, I.V.and Kozhevnikova, N.A. (2011). Phylogenetic and morphological evaluation of Wollea saccata (Nostocales, Cyanobacteria) isolated from the Yenissei River basin (Eastern Siberia, Russia). Fottea 11(1):99-106.

[13]- Lowry, O.H.; Rosebrough, N.J.; Farr, A.L.and Randall, R.J. (1951). Protein measurement with the Folin phenol reagent. J Biol Chem. 193:265-275.

[14]- Miazek, K. ;Iwanek, W.;Remacle, C.; Richel, A.and Goffin, D. (2015). Effect of metals, metalloids and metallic nanoparticles on microalgae growth and industrial product biosynthesis: a review. Int J Mol Sci 16(10):23929-23969.

[15]- Mishra, Y. K.; Murugan, N. A.;Kotakoski, J. and Adam, J. (2017). Progress in electronics and photonics with nanomaterials, 146: 304-307.

[16]- Morteza, E.; Moaveni, P.; Farahani, H.A. and Kiyani, M. (2013). Study of photosynthetic pigments changes of maize (Zea mays L.) under nano Tio2 spraying at various growth stages. Springer Plus, 2: 247-249.

[17]- Natalia ,F. M. and Elena K. $\quad$ Z.)2017). The Effect of Copper and SeleniumNanocarboxylatesonBiomassAccumulationandPhotosyntheticEnergyTransduction Efficiency of the Green Algae Chlorella vulgaris. Nanoscale Research Letters. 12:147.

[18]- Picraux Tom ,S. (2018)."Nanotechnology"، www.britannica.com, Retrieved pp 19-3 .

[19]- Reynolds, C. S. (1984). The ecology of fresh water phytoplankton". Cambridge univ. Press.

[20]- Rippka ,R. ; Deruelles , J.; Waterbury , J.R.; Herdman , M. and Stanier ,R.Y.(1979). Generic assignments ,strain histories and properties of pure.

[21]- Saxena,P. and Harish, (2018). Nanoecotoxicological Reports of Engineered Metal Oxide Nanoparticles on Algae, Springer International Publishing AG, part of Springer Nature 2018. 
[22]- Sebastian, S. (2015). Occurrence of filamentous algae and soil characteristics in the paddy fields of KUTTANAD and KOLE. Thesis. Lands of KERALA. CochinUniversity of Science and Technology. INDIA.

[23]- Sibi, G.; Kumar, D A.;Gopal ,T. ; Harinath, K.; Banupriya, S .and Chaitra, S. .(2017) . Metal Nanoparticle Triggered Growth and Lipid Production in Chlorella vulgaris, International Journal of Scientific Research in Environmental Science and Toxicology. 2(1):1-8.

[24]- Siddiqui, M.H. and Al-Whaibi, M.H. (2014). Role of Nano-SiO2 in germination of tomato (Lycopersicum esculentum Mill.) seeds. Saudi Biol. Sci., 21: 13-17.

[25]- Stein, J.R. (1973). Hand book of phycological methods Cambridge Univ. Press. Cambridge., UK.

[26]- Tang, Y. ; Xin, H. ; Yang, F. and Long, X..(2018). A historical review and bibliometric analysis of nanoparticles toxicity on algae, J Nanopart Res ,20:92.

[27]- Velmurugan, R., \& Incharoensakdi, A. (2017). MgO-Fe3O4 linked cellulase enzyme complex improves the hydrolysis of cellulose from Chlorella sp. CYB2. Biochemical engineering journal, 122, 22-30.

[28]- Veronica ,E. ; Leksono, A. and Arfiat, D.(2014). Effect of water Quality on Phytoplankton Abundance in Hampalam River and Fish pond of Batanjung Village . J.Environ. Sci. Tox. Food. Tech., 8(1):15-21.

[29]- Wiedeman,V. E. ;Walne , P. L. and Trainor, F.R. (1964). A new technique for obtaining axenic culture of algae. Can. J. Bot. 42(7): 958-959.

[30]- Yang, Y.; Xu, J.; Vail, D. and Weathers, P. (2011). Biomass and oil production by Ettlia oleoabundans grown on anaerobic digester effluent from 3 waste streams. Biores. Technol., 102: 5076-5082.

[31]- Zavřel, T., Sinetova, M. A., \& Červený, J. (2015). Measurement of chlorophyll a and carotenoids concentration in cyanobacteria. Bio-protocol, 5(9), e1467-e1467. 